Article

\title{
Leveraging COVID-19 Outbreak for Shaping a More Sustainable Consumer Behavior
}

\author{
Andreea Orîndaru 1,*, Maria-Floriana Popescu ${ }^{2}$ (D), Ștefan-Claudiu Căescu ${ }^{1}$, Florina Botezatu ${ }^{1}$, \\ Margareta Stela Florescu ${ }^{3}$ and Carmen-Cristina Runceanu-Albu ${ }^{4}$
}

1 Marketing Department, The Bucharest University of Economic Studies, 010404 Bucharest, Romania; stefan.caescu@mk.ase.ro (S..-C.C.); botezatuflor@gmail.com (F.B.)

2 International Business and Economics Department, The Bucharest University of Economic Studies, 010404 Bucharest, Romania; maria.popescu@rei.ase.ro

3 Administration and Public Management Department, The Bucharest University of Economic Studies, 010404 Bucharest, Romania; margareta.florescu@ari.ase.ro

4 Food and Tourism Engineering and Management Department, Transylvania University of Brașov, 500036 Brașov, Romania; carmen.albu@unitbv.ro

* Correspondence: andreea.orindaru@mk.ase.ro; Tel.: +40-721-326-957

\section{check for}

updates

Citation: Orîndaru, A.; Popescu, M.-F.; Căescu, Ș.-C.; Botezatu, F.;

Florescu, M.S.; Runceanu-Albu, C.-C.

Leveraging COVID-19 Outbreak for

Shaping a More Sustainable

Consumer Behavior. Sustainability

2021, 13, 5762. https://doi.org/

$10.3390 /$ su13115762

Academic Editors: Miguel Cuerdo

Mir, Luis Miguel Doncel Pedrera and Jorge Sainz-González

Received: 1 April 2021

Accepted: 18 May 2021

Published: 21 May 2021

Publisher's Note: MDPI stays neutral with regard to jurisdictional claims in published maps and institutional affiliations.

Copyright: (c) 2021 by the authors. Licensee MDPI, Basel, Switzerland. This article is an open access article distributed under the terms and conditions of the Creative Commons Attribution (CC BY) license (https:// creativecommons.org/licenses/by/ $4.0 /)$.
Abstract: Consumption has lately been under the microscope facing pressure from all stakeholders as principles of sustainability have gained more popularity. In this context, a new sustainable consumer model was born, referring to major shifts in buying and consumption habits. Nevertheless, these shifts were lagging as consumers resisted change in the comfort of old habits. This comfort was shaken up by the COVID-19 outbreak that forced us to rethink every aspect of our lives. Therefore, this crisis context seems the perfect opportunity to shift towards the sustainable consumer model. People's openness towards embracing new consumption habits was evaluated in a quantitative study where data was collected in two different moments: May 2020 and December 2020. Major results of our research show that people's lives were dominated in 2020 by uncertainty, especially when referring to their financial situation. Further on, consumers have already started to bring major shifts in their consumption habits because of this uncertainty. Among the most important shifts, there were more prudent purchase decisions, rising interest for discounted prices, increased likelihood of buying local and enhanced preference in buy fresh products instead of processed or semi-processed ones.

Keywords: covid-19; domestic consumption; consumer behavior; sustainability

\section{Introduction}

Today, almost everyone is worried about the future of our world. More general concerns such as global warming, an entire species going extinct due to carcinogens and/bacteria exposure, plus quite a few others, are prominent on everyone's mind. The consumer's emphasis on personal wellbeing is colliding with increasing concern in public health. Some critics refer to this new value as conscientious consumerism [1,2]. The translation of concern for sustainability to sustainable consumption is based on institutional awareness superiority enforced by its obligation on persons, resulting in better understanding between institutions and individuals [3-8].

The current paper adds to the existing conversations on these topics by evaluating how consumer behavior is significantly shifting in an era of major crisis like the COVID-19 crisis. Given the unusual high impact of this health crisis, the changes in consumer behavior have been equally surprising signaling that this might be the perfect window of opportunity to generate a major shift towards sustainable consumption. The major question that the current paper is trying to answer is "To what extent did consumer consumption actually change and in what ways did it change?" All these elements are explored in the current paper as a contribution to the ongoing conversations on how to definitively transition towards sustainable consumption. 
Through the literature review in the field of core concepts, such as "consumer behavior" and "sustainability", and by researching on Romanian citizens during the COVID-19 crisis, this paper aims to broaden the knowledge and build on the research carried in the field of changing consumption patterns, especially towards a greener and more sustainable way, aimed towards not returning to the status quo but instead ending the cycle of unsustainable means of consumption.

There are only a finite number of "good" ways to keep a company profitable while still reducing its carbon footprint and its impact on the climate; sustainability is one of them. Six out of every ten organizations that transition to a more sustainable business model now say that it has led to improved financial results [9].

Sustainability originated in the 1970s and 1980s as a concept driven primarily by societal, cultural, and economic factors. Bill McKibben, one of the environmentalists of the last three decades, dismisses sustainability as a "buzzless buzzword" that began as a mere "obfuscation" and has yet to impact the wider public [10-12]. According to Bill McKibben, sustainability never leaped common parlance and could never in the future. He believed in intellectual (and aesthetic) maturation (as factors for the growth and development of society) [12]. "Sustainability" and "sustainable development" have also been seen and been accused of being shallow words that promote endless environmental pollution while masking problems and avoiding change.

Even if sustainability is a "buzzword", as McKibben was stating, for sure, it is not "buzzless". Governments, community groups, organizations, and individuals have searched for the idea of "sustainability", a broader set of shared values and concepts that they believe are central to a safer, more stable, and more appealing environment. Not only is it a buzzword, but it is also a galvanizingly clear concept whose use encompasses a multitude of other trends, perhaps most notably environmental.

Mainly, "sustainability" is described as a way to counterbalance climate change [13], as a concept that people rely on as a counterweight when dealing with it. Sustainability can also be a means of noting how humans have set the Earth back from equilibrium. The findings of Jeffrey D. Sachs, who currently heads the Earth Institute at Columbia University, support the theory that we are now in the age of the Anthropocene, an epoch in which "human activity" has become "the primary force of the planet's climate" [14,15].

Environmentally associated problems like climate change, deforestation, and hazardous waste have developed a strong foothold, so it is crucial to discern it from this catchphrase: green marketing. This plan is based on creating and promoting green goods and emphasizing specific attributes when buying the merchandise [16-18]. Few businesses, such as Seventh Generation, have done well with green-branded goods, but most others have struggled. The demand for recycled and reused materials is open, fresh, and environmentally conscious. During the last two decades, nearly all firms have made a significant attempt to adapt their strategies to global warming's detrimental effects on the climate. Car manufacturers, for example, contribute significantly to environmental degradation, so they now produce more efficient vehicles. Many ads [19] let the public know that they use green, clean, non-polluting, and even environmentally friendly materials like wood, corn, rice, or palm oil.

Companies understand that environmental consciousness is growing among customers, and, to this effect, they would be able to pay a premium for ethically made goods (e.g., without harmful chemicals).

It is popular to characterize the new social institution in terms of the developing world as one of the market cultures. It is more than just because we live in a world full of things. That is because we live in a world that is increasingly focused on how and what people eat. We used to concentrate on our function in the business, namely, on our occupation. Increasingly, however, what we eat rather than what we do for a living is becoming an essential part of our identities. The wide variety of products and models encourages consumption decisions to be declarations about who we are, our beliefs, desires, emotions, perceptions, and relationships. 
Moreover, during cycles of economic depression, customers are also asked to keep the economies going. It follows the basic theory of supply and demand that if the demand for a product goes down, the offer would also decline. The response is very straightforward-it is a matter of sustainability. How someone treats money is all part of who someone is as a person. Therefore no one should ignore the decisions on what someone eats as trivial. Furthermore, what someone consumes impacts others on all three levels: personal, social, and economic [20].

As the education system, consumption is a class system: first and foremost, there is a disparity concerning the resources available to each person-and therefore based on the buying ability of resources, as well as on each person's knowledge of things. It means that not everyone experiences the world the same way, but others understand the logical, technical, or artistic aspects of the universe. In contrast, functional or cultural achievement remains invisible to others. In terms of fetishism, these persons do not bother with objects, and those that do are subject to the concept of valorization do not "consume" or, strictly speaking, do not deal with any object at all [21]. The driving force of consumerism is the exponential rise of individual spending. It is usually followed by reductions in budget spending to support third parties (mainly the government) and the overall reduction in wealth inequalities.

Currently, sustainable consumption is rising as a researched activity in the academic community. A source of these recent societal transformations has been applying social science theories, including economics, sociology, political science, and public policy [22-31]. The new interdisciplinary study area on sustainable consumption, alongside sustainable production and sustainable growth, is now referred to as sustainable consumption [32,33].

By comparison, the academic legislation has overlooked the study of sustainable use, even though ethical effects became apparent decades earlier. When it came to the principle of sustainable use, 178 countries agreed and ratified it in 1992 at the United Nations (UN) Convention on Environment and Development [34]. The Declaration, which emerged from the same year's United Nations Earth Summit, brought to the world's notice the two sides of the coin in terms of the influential forces underpinning global environmental risks: unsustainable and dangerous overproduction and use [34]. The legal scholar's silence on this topic is all the more perplexing considering that sustainable consumption is one of the core values towards human growth from the UN's perspective, a pledge enshrined in its Guidelines for Consumer Protection [35] and the 2030 Agenda for Sustainable Development [36].

According to George Loewenstein, a behavioral economist at Carnegie Mellon University, much of the brain is governed by unconscious mechanisms rather than conscious thought. Most of what happens in the brain is mental rather than cognitive. [37]

As a result, the global health crisis represents an impetus for a profound, structural transition to a more prosperous economy [38] that benefits both individuals and the world. The development of COVID-19 has highlighted the interaction between people and nature [39] and unveiled the underlying tenets of the trade-off we are constantly confronted with: humans have infinite desires, but the world has limited ability to meet them. Before the effect is detrimental, we must strive to recognize and appreciate the boundaries to which humans can drive nature. These constraints must be mirrored in our habits of consumption and output. As a result, the COVID-19 pandemic provides countries with an incentive to develop recovery strategies that can reverse current trends and shift our consumption and development habits toward a more prosperous future, near alignment with SDG 12: Ensure long-term demand and supply habits [36].

\section{The Transitioning towards a Sustainable Consumer Behavior}

As consumption has become an exceedingly important part of our daily lives, it has come to be treated as a subject deserving scholarly inquiry. This focus, though, is relatively new. Historically, the study of sociology and other research disciplines is dominated by what has been labeled as productivist bias. Production and function were preferred 
overconsumption by classical thinkers such as Adam Smith and Karl Marx and, until recently, by contemporary social observers [40,41]. Beginning in the 1960s, anthropologists, economists, political scientists, and sociologists began to objectively criticize this productivist bias by explaining the role of demand and consumers in industrial culture growth, both historically and empirically. Miller et al. (1998) describe three periods of consumer research, with the first beginning in the 1960s and culminating in the late 1970s with the loss of factory employment and conventional working-class society in Western societies [42]. Researchers found that consumption entered the social sciences during the second stage of consumer research, which continued from the late 1970s to the early 1990s. Consumption was recognized as a critical component of industrialization, rather than just a byproduct of it, at that time [43]. Interestingly, one might argue that a consumerist bias arose during this second stage when consumption was often examined independently from manufacturing processes. It was particularly true for research that focused on consumer's subjectivity and postmodern culture [44-51].

This neglect of productivity began to be rectified in the early 1990s and persists today throughout the third stage of consumer research, which links consumer behavior to worker care and the environmental impact of production and consumption. The historical history of consumerism, especially in the United States, is an expanding field of study [52-60]. Efforts to incorporate ethical, social, and political issues are now focused on the public, including the belief that customers are activists and people who can exercise social and political rights in the marketplace [61-65].

Many researchers have recently turned their focus to the environmental effects of consumption. Paul Ehrlich, who authored the well-known books "The Population Bomb" (1968) and "Population Explosion" (1990), has shifted his focus to arguing that "consumption factor" needs to be studied rather than population [66,67]. A worldwide consumer movement has also changed Norman Myer's focus on environmental impact, stating that we are in the middle of one of the most significant changes in the industry's history: the rise of the developing-country population [68]. The rapid increase in the numbers of these new customers poses us with one of the most significant potential challenges: how to accomplish ever-greater resource consumption—or an alternate sort—without drastically diminishing the economic foundation on which our economies rest [68]. Sustainable use is seen as a means for bettering the quality of living [69], both materially and environmentally. Both technology advancements [70] and marketplace strategies are essential aspects of sustainable consumption through [71]: shared and guaranteed basic needs of the global community; enhancing or creating intellectual capital; and social consciousness and equable spread of resources [72]. Research has shown that sustainable consumption is related to human growth but needs additional money from personal wages, informal jobs, and natural resources [72].

The subject of consumption is the arena of many determinations in the field of critical sociology, the ground on which the consumer's "right of preference" is readily assimilated to a veil of delusion. The dramatic increase in critique also signifies the passing of an age and the subsequent "normal transition" from that subject. Baudrillard's essay on the "consumption society" (1970) did not mean the end of the social form he was attempting to dismantle; on the contrary, it was the beginning of a new one [73,74]. His condemnation of the impact of consumption on human liberty and social relations has been prevalentconsidering his lack of motivation to leave this form of culture. On the opposite, the world of tangible products, sold or purchased, has never been so widespread (and, we may add, urgent) in our society as it is now, thanks to the apparent "virtualization" of commercial exchanges.

Consumers and end-of-chain consumers of products produced worldwide must accept additional obligations as a result of globalization. Consumerism helps to underwrite global socioeconomic, intergenerational, and ecological inequity in our world. There is no possible growth in the economy without expansion of demand fostered by the entire system, especially from customers. In modern times, it can be described as a society 
governed by a growth-based economy and succumbs to a market economy of growth. Humans are tempted to use things as a means to achieve a more extraordinary life and live to consume more things; it is, for that reason, that simple. The usage and consumption cannot occur if the environmental ecosystem hits its limits, as much as the oppression of scarce resources does.

Consumer behavior is described as consumers looking for, buying, using, reviewing, and disposing of, respectively, goods that meet their needs [75-77]. When resources are scarce, the actions of individuals involve factors that contribute to consumption and spending (time, capital, effort) [78]. It considers what/why/when/where/how often they buy it, how often they use it, how much they assess those decisions, and how they manage to dispose of it.

The study of consumer behavior started in the mid- to late-1960s. Since there was no tradition or body of scientific research to go on its own, marketing theorists often pulled in ideas from other scientific disciplines, including psychology (the individual), sociology (groups), social psychology (group influence), anthropology (society) and economics, to create a new discipline from the ground [79]. Up to this point, much of consumer behavior has been derived from economic theory, consumers seeking to make full use of their advantages (satisfactions). Later studies have shown that customers are as likely to buy impulsively and motivated not only by family and friends but also by emotions, advertisements, situations, and the feelings they are experiencing. The perspectives gained from each source work together to provide a complete image of customer behavior, taking into account both the cognitive and emotional decision-making aspects [80-82].

To better understand people's basic demands while protecting the environment, a definition for these "needs" has to be given. We all should benefit from growth. Social considerations and altruism are crucial for long-term success. As the world should be available for future generations, it must be preserved and restored. On the one hand, traditional forms of production and consumption and modern ones, like sustainable economies, are contrasted with conventional economic models. On the other hand, corporate values, business ethics, and corporate governance pose the challenge of integrating environmental and social concerns into corporate strategies.

Following debates about public goods, such as physiological and psychological needs, this distinction has proved biased and even unsustainable. Some sociologists and anthropologists believe that all needs are cultural. In contrast, others claim that products are merely used as a means of material culture from which groups attempt to enforce their boundaries. According to Baudrillard, the fundamental issue with most consumer culture consumption is that it reflects a long-suppressed appetite of those who live in it $[74,83,84]$.

However, the level of sophistication of consumption has risen over the years. Recent social trends should be included in the study of consumer preferences, including the following [85]:

- The triumph of the demand side over the supply side, as well as the rise of the customer as a sovereign subject willing to assert control over the market. New sources of knowledge and communication, ample opportunities, and new evaluation capabilities have altered consumption behavior. All of this affects both the selection of items to be consumed and how they are used/consumed.

- There will be new varieties of contact between consumers and firms because of freemarket standards being applied within self-regulation.

- The impact of the producer's marketplaces requires corporate ethics, market accountability, risk assessment, and audit in production.

- Brands play an important role in behavior because they affect family, community, education, the workplace, and everyday life and work, and they are part of a much larger scale of social networks.

- At the same time, new alliances between groups that are mutually opposed, such as customers and unions, and forces that transcend markets, would arise within the context of globalization. 
Finally, policies that target individual consumption often employ prescriptive elements (such as taxes or information) to justify consumers' behavior. Individuals can engage in sustainable development's social and environmental aspects, but institutional limits govern their responsibilities. As resources and processes are inseparable, behaviors can fundamentally alter our decisions and how our social class affects our thought patterns. The good news is that improvements in consumption are possible and should be welcomed.

To face the current growth demands, consumer-goods firms may need to take on a new strategy. Data-driven marketing, marketing via digital means [86], and programmatic mergers and acquisitions [87] would be significant for their goals to be achieved.

According to a McKinsey \& Company report [88], based on both CEO surveys and consumer research, there were identified ten trends (Figure 1) that are believed to shape the industry over the following years (primarily driven by COVID-19).

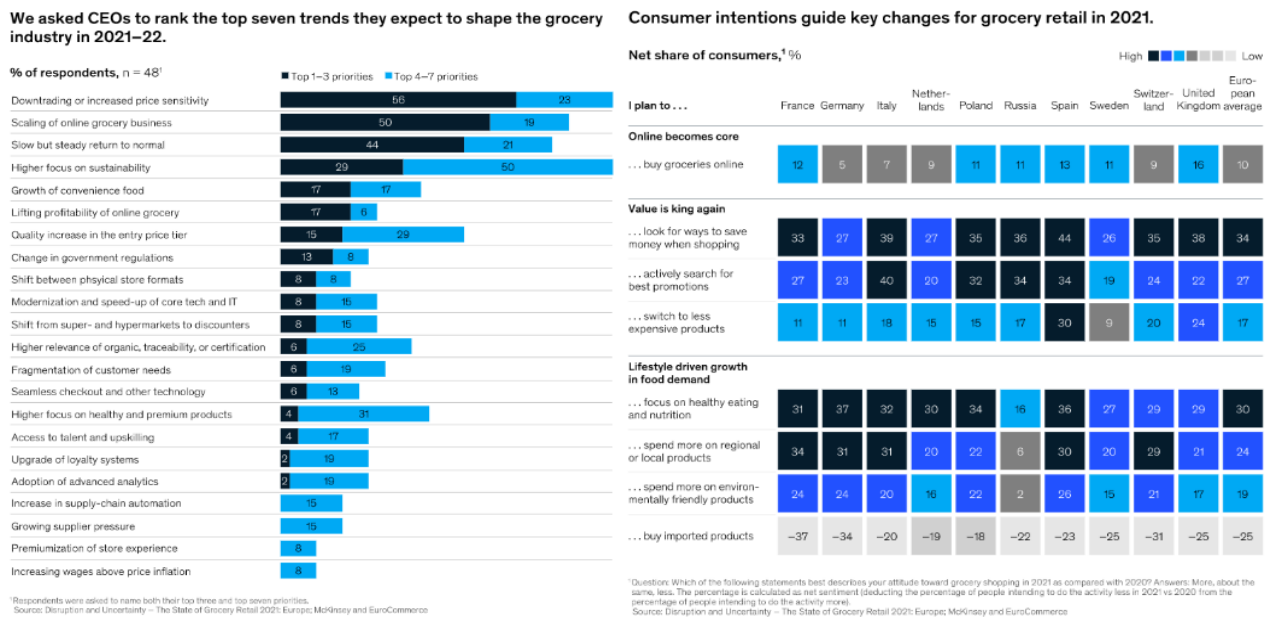

Figure 1. Key trends shaping the industry: CEOs' views of fundamental industry-shaping changes, and shopping intentions of consumers.

The COVID-19 crisis has intensified the movement toward more organic, affordable, and local goods, with no sign of abating. Across Europe, $30 \%$ of respondents intend to spend more on healthy eating and wellness in 2021 versus 2020, 24\% plan to spend more on regional and local goods, and 19\% plan to spend more on environmentally friendly products. Many individualized factors continue to affect these patterns, including economic conditions [89]. Consumers who have more disposable income tend to be less frugal in their spending habits and more open to health and nutrition. To a large degree, lower-income populations concentrate on what they can afford and less on what they need concerning healthier food choices.

Based on previous research projects and studies, their results, and their assumptions, the current approach was designed to discover the underlying changes in people's consumption behavior in the middle of the COVID-19 crisis in 2020, aiming to transition towards sustainable consumption. The design of this research and its results are described in the next section.

\section{Consumers' Perceptions Evolution on Income and Consumption during the Major COVID-19 Outbreak in 2020}

\subsection{Methodology}

Starting from the significant impact that the COVID-19 outbreak had on all aspects of human life, the need for further research that would ensure a higher understanding of what that impact included, is increasing in an era of uncertainty. For this, a research project was developed to explore how perceptions that define consumer behavior have changed during the significant outbreak of COVID-19 in 2020. The two significant areas explored were related to perceptions on income and perceptions on consumption. Exploring such 
perceptions and how they have evolved in uncertain times is crucial to understanding consumer behavior's major shifts and leveraging them for a long-lasting change in the way we consume.

As perceptions are difficult to predict, this task becomes even more difficult in times of increased social and economic uncertainty, like the significant COVID-19 outbreak in 2020. In this context, this research was developed to get direct feedback from consumers right in the middle of the 2020 COVID-19 outbreak. The research objectives included: identifying the COVID-19 impact on consumers' perceptions on income and their expected income evolution, discovering changes in the evolution of consumers' perceptions in 6 months, describing perceived changes in consumption levels and patterns and how they evolve during 2020, and discovering any changes in behavior or preferences while facing environmental changes. In order to achieve these objectives, primary information was gathered in a quantitative study that used two samples with data collection happening, respectively, in May 2020 and in December 2020 (respondents included in one of the samples may or may not have been included in the other sample, but a similar pattern in structuring the samples was followed so that comparison between samples is significant and relevant). In a research design focused on Romania's adult population (all the respondents included in the sample were at least 18 years old, for compliance with the ESOMAR code of ethics), the May sample included 1015 participants, while the December sample included 1020 participants. Both of these samples were built based on online panels ensuring the representativeness of the entire adult population. Both the research samples' size ensures a $\pm 3 \%$ margin of error and a $95 \%$ confidence level. Data collection was completed using a survey as a research method and an online interview as a data-gathering tool. The interview guide consisted of 39 questions, and it gathered from general to specific feedback on respondents' perception on various elements of perception related to COVID-19. The interview guide also included questions about gender, income, age, education, marital status, employment industry, and residential environment (urban or rural). All this information is used in discovering how perceptions differ across different backgrounds and personal situations.

Choosing the Romanian population to develop our research was determined by the patterns in the national consumer behavior. Being an ex-communist country, people tend to still have influences from that time, wounds that they are trying to fill by unconscious buying behavior. In this context, transitioning towards sustainable consumer behavior is even more challenging in such a setup. When it comes to the national context and reaction to the COVID-19 outbreak in Romania, it can be described as follows: on the 16th of March 2020, a national lock-down was in place throughout the country. This lock-down with significant restrictions lasted until the 15th of May 2020, and after this date, different types of local or regional curfew or strict distancing rules were installed. Even though there was no other nation-wide lock-down, many restrictions prevented life from going back to normal by the end of 2020. The first data collection happened during the national lock-down (as the data gathering happened at the beginning of May: 4th-8th of May 2020), while the second data collection happened while local or regional curfew nation-wide restrictions were applied when it comes to social distancing or mask-wearing.

Based on this raw information, an analysis was conducted from a univariate approach, with several key points being studied and a bivariate approach, where some correlation tests (Spearman's) are described to determine various elements' impact on consumers' perceptions (all the correlation coefficients mentioned in the following analysis were significant at the 0.01 level—two-tailed). This analysis was conducted using the IBM SPSS Statistics software (version 27), a software developed by Norman H. Nie for SPSS Inc. which was later bought by IBM, Armonk, NY, USA.

\subsection{Results}

Our research design followed a funnel structure, and the research results are explored similarly: from a broader perspective to a narrower understanding of consumers' perception of their influence factors, as well as their evolution. Some of the results are presented 
in a 6-months perspective by comparing the results obtained on the two samples. In comparison, other results were computed for the whole 2-phase sample consisting of the two separate samples, as the information gathered was relevant for the entire population.

\subsubsection{Income Perceptions}

Our research's starting point was focused on perceptions related to the professional life and, more specifically, on income evolution as opposed to the past (having in mind a time frame of 3 months) or to the future. When it comes to the impact that this pandemic had on the respondents' professional life, $78.2 \%$ of the May respondents and $77.5 \%$ of the December respondents mentioned that this outbreak had some sort of impact on their professional life (as it can be seen in Figure 2a,b).

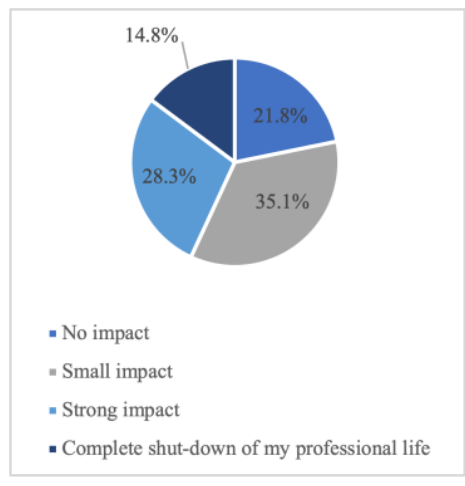

(a)

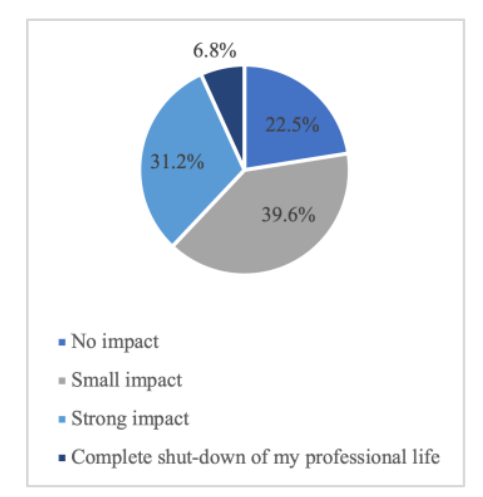

(b)

Figure 2. Respondents' perception on the impact of COVID-19 on their professional life: (a) May sample; (b) December sample.

For more than 3 people out of 4, the COVID-19 outbreak had some impact on professional life. This element seems to generate a negative perspective about everything that might happen in the future since there is a low-impact but significant correlation between respondents' view on professional life impact and their estimation related to them having the same job in the next 3 months (the Spearman correlation coefficient was 0.132 when computed for the whole 2-phase sample-while the May coefficient was 0.240 and the December coefficient was 0.216 -meaning that the stronger the impact on the professional life, the more likely are the respondents to estimate that they will not have the same job in the next 3 months). Even more than that, the more pessimistic the respondents view on the perceived impact of the COVID-19 outbreak, the more likely they seem to estimate that they might need to use their savings or even borrow money from friends or even banks (for the whole 2-phase sample, there was a 0.225 Spearman coefficient measuring the correlation between the perceived impact variable and the one that measured respondents' perception over their management of resources for covering the next 3 months' expenses-this was a nominal variable that coded alternatives as it follows: " $1=$ my income will be enough", " 2 = I will have to use my savings", " 3 = I will have to borrow small amounts of money from my friends", " 4 = I will have to borrow money from banks", " 5 = I do not know").

When it comes to the respondents' perception of their financial situation compared to 3 months ago, Figure 3a,b show how this perception has gotten a bit worse between May and December. A total of $64 \%$ of the May respondents mentioned that their financial situation is worse, while only $44.4 \%$ of the December respondents described their family's financial situation as worse. It proves that in the middle of a crisis, like the one generated by the COVID-19 outbreak, people tend to see everything in dark shades while getting used to the situation and understanding at least to some extent its spread and impact can lead to more optimistic views. Additionally, when evaluating this variable with the variable measuring respondents' evaluation over their income, a -0.166 correlation coefficient (computed for the whole 2-phase sample; the same coefficient computed for the December 
sample was a bit more significant: -0.188) shows that the lower income respondents have, the worse they evaluated their financial situation as compared to 3 months ago. Such a result might prove that low-income people tend to have a more pessimistic view of the impact of a crisis like the COVID-19 outbreak.

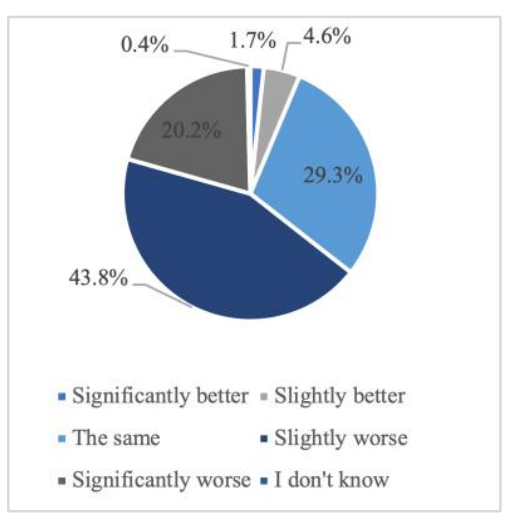

(a)

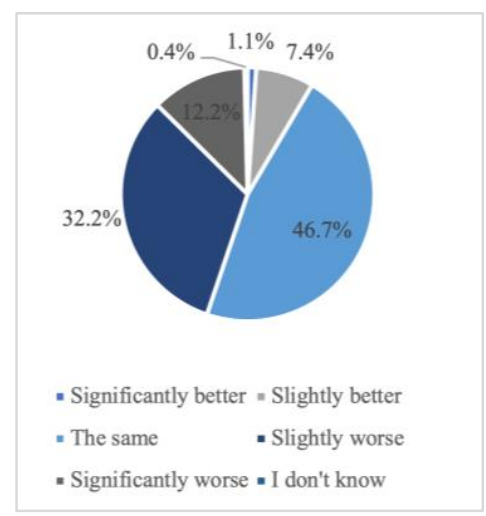

(b)

Figure 3. Respondents' evaluation on their family's financial situation compared to 3 months: (a) May sample; (b) December sample.

The same principle was also confirmed when respondents in both samples were asked to estimate their family's financial situation in the next 3 months: if in the May sample only $48.2 \%$ of the respondents believed that their situation would be better (slightly better or significantly better) in the next 3 months, in the December sample $60.8 \%$ of the respondents had the exact estimation for their future financial situation (as can be seen in Figure $4 a, b$ ).

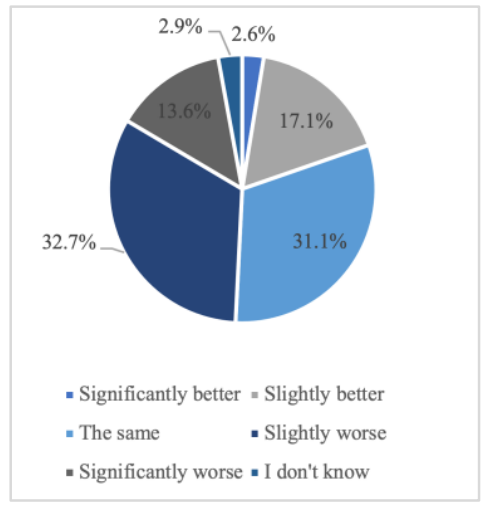

(a)

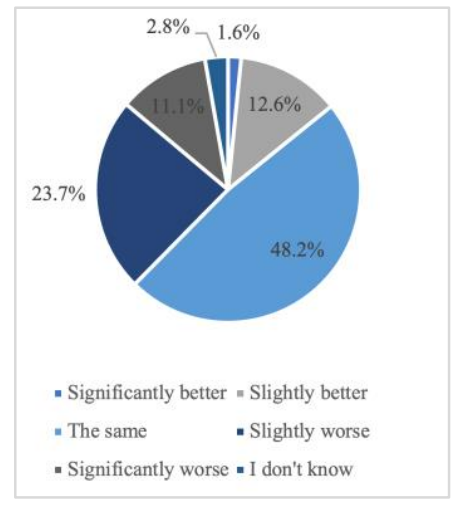

(b)

Figure 4. Respondents' estimation on their family's financial situation in the next 3 months: (a) May sample; (b) December sample.

So, when taking into account these answers in correlation with the fact that $93.9 \%$ of the December respondents thought the COVID-19 outbreak would strongly impact the national economy and that $80 \%$ of the same December sample thought that the unemployment rate in Romania would be higher in the next 3 months, we might conclude that while people are pessimistic about the general influence of this outbreak at the national level, they seem to have a quite unexpectedly optimistic view on their financial evolution in the next 3 months. At the same time, there is a low impact direct correlation between the variable measuring respondents' estimation on their future financial situation in the next 3 months and their estimation related to the national unemployment rate (a 0.246 Spearman coefficient for the whole 2-phase sample and a 0.292 Spearman coefficient for the December sample shows 
that the worse the estimated financial situation, the worse perspective on the national unemployment level).

When it comes to their job, $76.3 \%$ of the May respondents and $71.6 \%$ of the December respondents estimated that they will have the same job in 3 months (as shown in Figure 5a,b). So, roughly 3 in 4 people estimate that they will have the same job. At the same time, there is a low impact direct correlation between this variable and respondents' estimation of whether they will have to take loans in order to support their expenses (a 0.206 correlation coefficient computed for the whole 2-phase sample and a 0.298 correlation coefficient computed for the December sample confirm this).

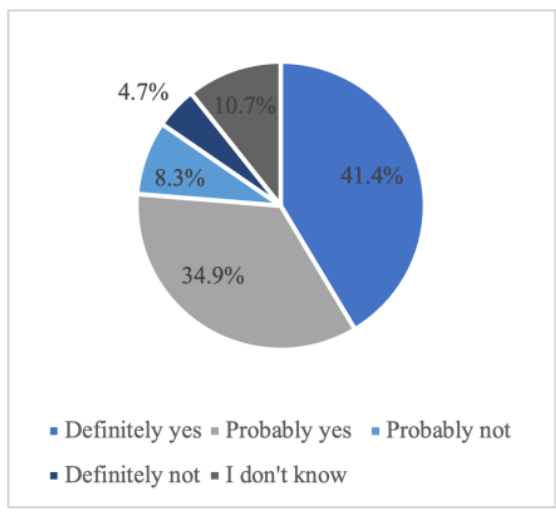

(a)

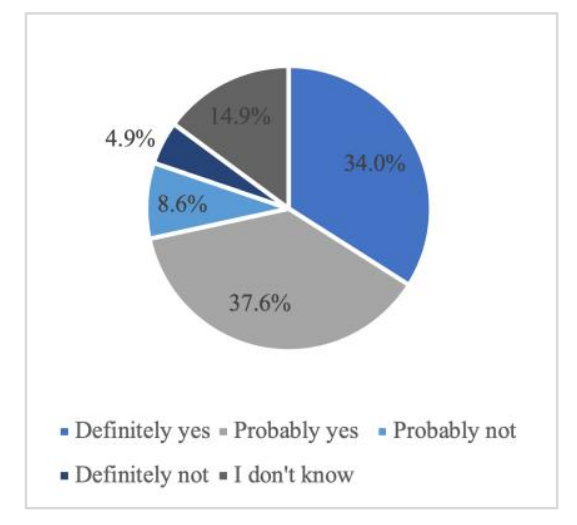

(b)

Figure 5. Respondents' estimation whether they will have the same job in 3 months: (a) May sample; (b) December sample.

Related to the connection between respondents' estimation on the financial situation of their family for the next 3 months and their estimation of whether in 3 months they will have the same job, there is a very slight direct correlation: the worse they estimate their financial situation, the more likely they are to predict that they will not have the same job (0.127 Spearman coefficient was computed for the whole 2-phase sample, while for the May sample this coefficient was 0.231).

All these results related to respondents' perception, evaluation, and estimation of their income and professional life status are the underlying determinants of their perception, evaluation, and estimation of their consumption behavior, which is analyzed further in the following sub-section.

\subsubsection{Consumption Perceptions}

In the second part of our research project, our intention shifted from evaluating income and professional life-related variables towards understanding consumption patterns and perceptions. One variable that links variables related to income and professional life to those connected to consumer behavior is evaluating the respondents' perception of the average price for frequently bought products compared to 3 months ago. As shown in Figure $6 \mathrm{a}, \mathrm{b}, 74.3 \%$ of the May respondents and $68.5 \%$ of the December respondents perceived the average price for their frequently bought products to be (slightly or significantly) higher as compared to 3 months ago. Furthermore, based on the results related to this variable's correlation with the one measuring respondents' perception over the average price of frequently bought products in the following 3 months, it seems like a history of rises in the average price is a strong enough base for estimating that in the future prices will keep on rising (the 0.461 correlation coefficient for the whole two-phase sample proves a medium impact direct relationship between these two variables). Furthermore, there is also a small impact in the direct correlation between this variable and the one measuring respondents' perceptions over their financial situation in the next 3 months (based on a 0.155 coefficient computed for the whole two-phase sample and a 0.198 coefficient computed 
for the December sample). It is likely that uncertainty relative to own personal financial situation is a cause of the pessimistic view over the market prices; therefore, it is likely that these perceptions are uncorrelated to the reality in the market when referring to prices.

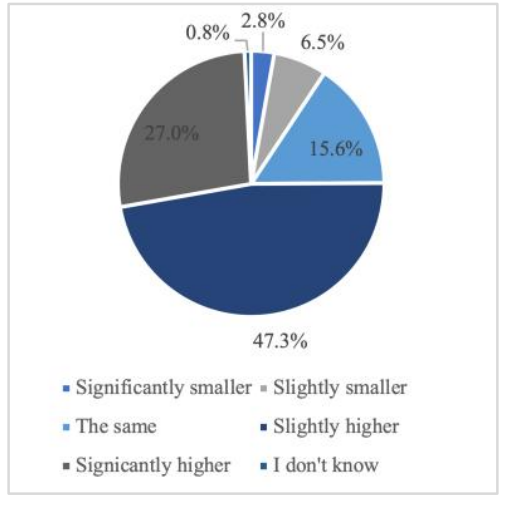

(a)

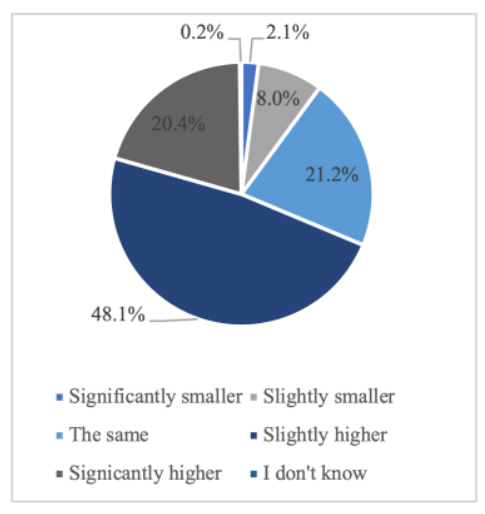

(b)

Figure 6. Respondents' perception on the average price for frequently bought products as compared to 3 months ago: (a) May sample; (b) December sample.

When studying the buying behavior as it is perceived by the respondents, while $51 \%$ of the May respondents and $64 \%$ of the December respondents said that their food consumption has not changed, $76.4 \%$ of the May respondents and $74 \%$ of the December respondents mentioned that their buying decisions have become more cautious. Moreover, $75.9 \%$ of the May respondents and $71.2 \%$ of the December respondents said they have significantly reduced expenditure on products and services that do not solve a basic need. Moreover, almost 1 in 2 respondents (48.2\% of the respondents in the whole twophase sample) mentioned that they currently buy more discounted products. All these results show significant changes in the way consumers bought products during this time of significant changes. This perspective was also confirmed by the correlation between different consumer behavior changes, as shown in bold characters in Table 1. Changes in food consumption towards a more cautious approach might signal that consumers are diminishing their food waste and contributing towards a more sustainable approach in the way they consume. Diminishing food waste is an essential objective since, globally, we are wasting 931 million tons of food, out of which 61\% comes from households [90]. On the other hand, this more cautious behavior can be a result of increased worries related to present and future financial situation, and it may not be a result of increased awareness of the impact of the unsustainable consumption behavior, which unfortunately might mean that once these worries vanish, the unsustainable behavior will be resumed. 
Table 1. Respondents' estimation on their consumption behavior (the whole 2-phase sample).

\begin{tabular}{|c|c|c|c|c|c|c|c|}
\hline & & $\begin{array}{l}\text { Food Consumption } \\
\text { ("1 = Yes, It Has } \\
\text { Increased in Quantity"; } \\
\text { “2 = No, It Has Not } \\
\text { Increased in } \\
\text { Quantity") }\end{array}$ & $\begin{array}{l}\text { My Buying Behavior } \\
\text { Has Not Changed } \\
\text { (“1 = Yes"; “2 = No"; } \\
\text { “3 = I Do Not Know") }\end{array}$ & $\begin{array}{c}\text { My Buying Decisions } \\
\text { Have Become More } \\
\text { Cautious ("1 = Yes"; } \\
\text { “2 = No"; “3 = I Do Not } \\
\text { Know") }\end{array}$ & $\begin{array}{l}\text { I Have Significantly } \\
\text { Reduced Expenditure } \\
\text { on Products and } \\
\text { Services That Do Not } \\
\text { Solve a Basic Need } \\
\text { ("1 = Yes"; “2= No"; } \\
\text { "3 = I Do Not Know") }\end{array}$ & $\begin{array}{c}\text { The Buying } \\
\text { Decisions Take } \\
\text { Longer ("1 = Yes"; } \\
\text { "2= No"; ; } 3=\text { I Do } \\
\text { Not Know") }\end{array}$ & $\begin{array}{l}\text { We Currently Buy } \\
\text { More Discounted } \\
\text { Products } \\
\text { ("1=Yes"; } \\
\text { “2= No"; ; } 3=\text { I Do } \\
\text { Not Know") }\end{array}$ \\
\hline \multirow{3}{*}{$\begin{array}{c}\text { Food consumption (" } 1=\text { yes, it } \\
\text { has increased in quantity"; } \\
\text { "2= no, it hasn't increased in } \\
\text { quantity") }\end{array}$} & $\begin{array}{c}\text { Spearman's rho } \\
\text { Correlation Coefficient }\end{array}$ & 1.000 & -0.042 & $0.088^{* *}$ & 0.073 ** & $0.176^{* *}$ & $0.112 * *$ \\
\hline & Sig. (2-tailed) & . & 0.059 & 0.000 & 0.001 & 0.000 & 0.000 \\
\hline & $\mathrm{N}$ & 2035 & 2035 & 2035 & 2035 & 2035 & 2035 \\
\hline \multirow{3}{*}{$\begin{array}{l}\text { My buying behavior hasn't } \\
\text { changed (" } 1=\text { yes"; “ } 2=\text { no"; } \\
\text { "3 = I don't know") }\end{array}$} & $\begin{array}{l}\text { Spearman's rho } \\
\text { Correlation Coefficient }\end{array}$ & -0.042 & 1.000 & -0.040 & 0.023 & -0.012 & $0.044^{*}$ \\
\hline & Sig. (2-tailed) & 0.059 & . & 0.075 & 0.305 & 0.588 & 0.045 \\
\hline & $\mathrm{N}$ & 2035 & 2035 & 2035 & 2035 & 2035 & 2035 \\
\hline \multirow{2}{*}{$\begin{array}{l}\text { My buying decisions have } \\
\text { become more cautious } \\
\text { (" } 1=\text { yes"; “ } 2=\text { no"; } \\
\text { " } 3=\text { I don't know") }\end{array}$} & $\begin{array}{l}\text { Spearman's rho } \\
\text { Correlation Coefficient }\end{array}$ & $0.088^{* *}$ & -0.040 & 1.000 & $0.420 * *$ & $0.352 * *$ & $0.228^{* *}$ \\
\hline & Sig. (2-tailed) & 0.000 & 0.075 & . & 0.000 & 0.000 & 0.000 \\
\hline \multirow{3}{*}{$\begin{array}{l}\text { I have significantly reduced } \\
\text { expenditure on products and } \\
\text { services that do not solve a basic } \\
\text { need ("1 = yes"; “ } 2=\text { no"; } \\
\text { "3 = I don't know") }\end{array}$} & $\begin{array}{c}\text { Spearman's rho } \\
\text { Correlation Coefficient }\end{array}$ & 0.073 ** & 0.023 & $0.420 * *$ & 1.000 & $0.339^{* *}$ & $0.248^{* *}$ \\
\hline & Sig. (2-tailed) & 0.001 & 0.305 & 0.000 & . & 0.000 & 0.000 \\
\hline & $\mathrm{N}$ & 2035 & 2035 & 2035 & 2035 & 2035 & 2035 \\
\hline \multirow{3}{*}{$\begin{array}{l}\text { The buying decisions take } \\
\text { longer (" } 1=\text { yes"; " } 2=\text { no"; } \\
\text { " } 3=\text { I don't know") }\end{array}$} & $\begin{array}{l}\text { Spearman's rho } \\
\text { Correlation Coefficient }\end{array}$ & $0.176^{* *}$ & -0.012 & $0.352 * *$ & $0.339 * *$ & 1.000 & $0.311^{* *}$ \\
\hline & Sig. (2-tailed) & 0.000 & 0.588 & 0.000 & 0.000 & . & 0.000 \\
\hline & $\mathrm{N}$ & 2035 & 2035 & 2035 & 2035 & 2035 & 2035 \\
\hline \multirow{3}{*}{$\begin{array}{c}\text { We currently buy more } \\
\text { discounted products (" } 1=\text { yes"; } \\
\text { "2= no"; " } 3=\text { I don't know") }\end{array}$} & $\begin{array}{c}\text { Spearman's rho } \\
\text { Correlation Coefficient }\end{array}$ & $0.112 * *$ & $0.044^{*}$ & $0.228^{* *}$ & $0.248^{* *}$ & $0.311^{* *}$ & 1.000 \\
\hline & Sig. (2-tailed) & 0.000 & 0.045 & 0.000 & 0.000 & 0.000 & . \\
\hline & $\mathrm{N}$ & 2035 & 2035 & 2035 & 2035 & 2035 & 2035 \\
\hline
\end{tabular}

** Correlation is significant at the 0.01 level (2-tailed). ${ }^{*}$ Correlation is significant at the 0.05 level (2-tailed). 
Going one step further in evaluating consumption behavior changes, what types of shops were preferred by the respondents based on their ranking in the two samples are presented in Table 2. As it can be observed, the two most popular suppliers are supermarkets and hypermarkets in both samples. However, when we look deeper, in order to get a deeper understanding of how the purchases sources have changed during this time, we can see that the window of change might already be closing: for example, the percentage of users that bought their products from convenience stores primarily fell by approximately $10 \%$, while the percentage of respondents that bought their products from the hypermarket met an increase of approximately $5 \%$. Simultaneously, the percentage of respondents who bought their products from the farmers' market primarily met an increase of approximately $6 \%$. Buying from the farmers market is one dimension of buying local, a behavior that is supporting a sustainable approach on multiple levels: environment (due to lower energy costs), economy (due to the support granted to the local and national economy), and community (as by buying local we offer support to the people around us) [91]. When it comes to online suppliers, small producers were less preferred in December than May, which might be because consumers came back slowly to the farmers' market once the restrictions made it possible. Further, we must mention the online suppliers like restaurants/fast-food were unappealing for both samples. It might be a sign that consumers are moving more and more towards preparing their meals at home, a trend that was also confirmed in other research projects on COVID-19. Additionally, since buying online from super/hypermarkets was equally unappealing for both samples, there is still space for educating the consumer towards embracing online shopping towards the sustainable consumer. These choices for food supplies can relate to shoppers searching for convenience and diminishing their exposure to unnecessary health risk.

Table 2. Respondents' ranking for products sources during the curfew (the whole 2-phase sample).

\begin{tabular}{|c|c|c|c|c|c|c|c|c|}
\hline Type of Supplier & Sample & $\begin{array}{l}1 \text { (the Most } \\
\text { Important) }\end{array}$ & 2 & 3 & 4 & 5 & 6 & $\begin{array}{l}7 \text { (the Least } \\
\text { Important) }\end{array}$ \\
\hline \multirow{2}{*}{ Supermarket } & May & $35.00 \%$ & $24.40 \%$ & $13.50 \%$ & $11.70 \%$ & $5.40 \%$ & $4.50 \%$ & $5.50 \%$ \\
\hline & December & $35.00 \%$ & $25.90 \%$ & $13.60 \%$ & $10.90 \%$ & $6.50 \%$ & $3.50 \%$ & $4.60 \%$ \\
\hline \multirow{2}{*}{ Convenience store } & May & $17.20 \%$ & $23.30 \%$ & $23.80 \%$ & $16.30 \%$ & $8.70 \%$ & $5.60 \%$ & $5.10 \%$ \\
\hline & December & $11.50 \%$ & $17.80 \%$ & $25.80 \%$ & $20.10 \%$ & $8.80 \%$ & $8.60 \%$ & $7.40 \%$ \\
\hline \multirow{2}{*}{ Hypermarket } & May & $35.20 \%$ & $19.90 \%$ & $13.50 \%$ & $13.70 \%$ & $7.70 \%$ & $6.10 \%$ & $3.90 \%$ \\
\hline & December & $38.70 \%$ & $22.30 \%$ & $13.10 \%$ & $12.50 \%$ & $6.70 \%$ & $4.50 \%$ & $2.20 \%$ \\
\hline \multirow{2}{*}{$\begin{array}{l}\text { Online (small } \\
\text { producers) }\end{array}$} & May & $2.50 \%$ & $8.60 \%$ & $11.20 \%$ & $14.80 \%$ & $26.20 \%$ & $19.90 \%$ & $16.80 \%$ \\
\hline & December & $1.90 \%$ & $6.60 \%$ & $8.40 \%$ & $13.40 \%$ & $27.50 \%$ & $22.90 \%$ & $19.30 \%$ \\
\hline \multirow{2}{*}{$\begin{array}{c}\text { Online (fast } \\
\text { food/restaurant) }\end{array}$} & May & $0.70 \%$ & $4.30 \%$ & $8.50 \%$ & $11.00 \%$ & $21.30 \%$ & $25.80 \%$ & $28.40 \%$ \\
\hline & December & $1.30 \%$ & $4.50 \%$ & $9.50 \%$ & $12.50 \%$ & $19.70 \%$ & $25.00 \%$ & $27.50 \%$ \\
\hline \multirow{2}{*}{$\begin{array}{c}\text { Online } \\
\text { (super/hyper-market) }\end{array}$} & May & $3.00 \%$ & $5.40 \%$ & $9.00 \%$ & $11.30 \%$ & $20.80 \%$ & $30.50 \%$ & $20.00 \%$ \\
\hline & December & $3.30 \%$ & $5.60 \%$ & $7.80 \%$ & $11.80 \%$ & $22.20 \%$ & $27.70 \%$ & $21.60 \%$ \\
\hline \multirow{2}{*}{ Farmers' market } & May & $6.40 \%$ & $14.10 \%$ & $20.50 \%$ & $21.10 \%$ & $10.00 \%$ & $7.60 \%$ & $20.30 \%$ \\
\hline & December & $8.20 \%$ & $17.30 \%$ & $21.70 \%$ & $18.80 \%$ & $8.70 \%$ & $7.60 \%$ & $17.70 \%$ \\
\hline
\end{tabular}

When it comes to the types of products consumers buy, an overview is displayed in Table 3. Based on the data presented in this table, we can argue that there is a dominant preference for buying fresh products from either individual producers or supermarkets and hypermarkets in both samples. When looking at this piece of information in correlation with how unappealing are industrially processed and semi-processed products, we can see this as a sign that the consumer is opened towards embracing a healthier lifestyle, and together with that, a sustainable purchasing behavior. The link between eating less unprocessed, fresh, and organic products is part of the sustainable consumption pattern, as Vermier et al. [92] argues. Their research mentions that examples of environmentally sustainable food consumption (ESFC) include buying locally or organically produced food [92]. 
Table 3. Respondents' ranking for different product categories during the curfew (the whole 2-phase sample).

\begin{tabular}{|c|c|c|c|c|c|c|}
\hline Product Categories & Sample & $\begin{array}{l}1 \text { (the Most } \\
\text { Important) }\end{array}$ & 2 & 3 & 4 & $\begin{array}{l}5 \text { (the Least } \\
\text { Important) }\end{array}$ \\
\hline \multirow{2}{*}{$\begin{array}{l}\text { Traditionally processed and } \\
\text { semi-processed }\end{array}$} & May & $10.00 \%$ & $24.10 \%$ & $30.50 \%$ & $26.70 \%$ & $8.70 \%$ \\
\hline & December & $11.20 \%$ & $23.80 \%$ & $31.10 \%$ & $26.30 \%$ & $7.60 \%$ \\
\hline \multirow{2}{*}{ Fresh from individual producers } & May & $31.80 \%$ & $26.70 \%$ & $23.00 \%$ & $13.30 \%$ & $5.20 \%$ \\
\hline & December & $30.30 \%$ & $27.50 \%$ & $20.90 \%$ & $15.50 \%$ & $5.80 \%$ \\
\hline \multirow{2}{*}{ Organic } & May & $9.00 \%$ & $16.20 \%$ & $22.60 \%$ & $21.00 \%$ & $31.20 \%$ \\
\hline & December & $8.80 \%$ & $15.60 \%$ & $23.20 \%$ & $20.60 \%$ & $31.80 \%$ \\
\hline \multirow{2}{*}{$\begin{array}{l}\text { Industrially processed and } \\
\text { semi-processed }\end{array}$} & May & $3.20 \%$ & $12.60 \%$ & $10.60 \%$ & $25.70 \%$ & $47.90 \%$ \\
\hline & December & $3.60 \%$ & $13.60 \%$ & $12.20 \%$ & $24.60 \%$ & $46.00 \%$ \\
\hline \multirow{2}{*}{$\begin{array}{l}\text { Fresh from supermarket and } \\
\text { hypermarket }\end{array}$} & May & $46.00 \%$ & $20.30 \%$ & $13.30 \%$ & $13.30 \%$ & $7.10 \%$ \\
\hline & December & $46.20 \%$ & $19.50 \%$ & $12.50 \%$ & $13.00 \%$ & $8.80 \%$ \\
\hline
\end{tabular}

When we look at the correlation between respondents' interest in fresh products from individual producers and their interest in industrially processed and semi-processed products, a -0.378 correlation coefficient (computed for the whole 2-phase sample) demonstrates that the higher a customer ranks fresh products in their preferences, the lower they rank industrially processed and semi-processed products.

Referring to respondents' estimation of whether they will specifically be interested in buying from local and national producers in the next few months, $81.8 \%$ of the May respondents and $77.5 \%$ of the December respondents agree on their interest in that direction, with an average of $79.6 \%$ when it comes to the whole two-phase sample. It might be a clear signal that in this context, consumers are more open to embracing a local-oriented buying behavior, and the slight decrease between May and December might signal again that this window for change might be closing more and more as consumers perceive that we are moving further and further away from the crisis key point.

\section{Discussion}

The results gathered in this research project are partially confirmed by previous research approaches and are partially bringing a new light in areas previously ignored or not well enough studied. Using as a starting point consumers' perception and take on their financial situation and their overall professional life is argued by the fact that consumers' estimation of their future financial situation is a salient indicator of "consumer confidence" that is one predictor of consumers buying behavior. As Solomon et al. [93] show, "when people are pessimistic about their prospects and the state of the economy, they tend to cut back their spending and take on less debt." The respondents' estimation and perception that their financial situation is mostly worse or significantly worse than 3 months ago are consistent with the Eurostat results showing a decrease of $4.8 \%$ in 2020 in the total employment income at the EU level [94]. When estimating their future financial situation, respondents proved a pretty optimistic perspective on their future, which might result from our culture's optimistic bias discovered by Druică et al. [95]. All these elements related to income and perception of the financial present and future situation are essential in understanding the underlying elements that influence consumer behavior and how it is exposed to changes in the COVID-19 era. These results show how uncertainty has the power to influence consumers' dark views over their financial outcomes. Moreover, the moment this uncertainty becomes a bit more specific (or maybe, the moment consumers get used to that level of uncertainty), expectations and perception become more optimistic for the Romanian consumer.

When referring to the impact of perceptions over the financial situation, perceiving that the financial situation is currently worse than it used to be 3 months ago might also be one of the causes why respondents believed that prices have increased during the outbreak. Besides their subjective bias, respondents' perception of price increases is supported by a report issued by Euromonitor [96] arguing that "spending on essentials such 
as food, non-alcoholic beverages, and housing is likely to rise mainly due to higher costs of living (especially food prices)", a statistic also consistent with $57.7 \%$ of the respondents that said that their food consumption did not increase in terms of quantity. Despite not changing in terms of quantity, for sure, the habits that led the way while purchasing have changed. Some of the changes discovered in our research prove that consumers are making more prudent purchasing decisions while buying more and more discounted products. It confirms a study conducted by McKinsey [88] showing that 12 disruptive trends have battered the model for the consumer goods, out of which two are relevant in the current context: "conscious eating and living" and "steady rise of discounters" (and the COVID-19 impact enhanced both these trends). One-way consumer behavior seems to be moving more and more towards a sustainable model: bringing awareness in the way people spend money is ground zero in understanding which decisions serve them and which do not serve them. Respondents in this research project confirmed that their awareness level has changed in two significant directions: general awareness and ways towards more efficient resource management.

When speaking about surprising research results, we can include in this category the fact that online shopping from supermarkets or hypermarkets was rather unappealing for the Romanian consumers, as opposed to other statistics that showed different results [88,97]. One reason for such an odd result might relate to the fact that supermarket or hypermarket shopping in Romania is not a general service and is most frequent in big cities while being a rare service in smaller cities. These results offer another perspective on changing buying behavior: technology adoption for a more efficient resource usage has still a long way to expand in Romania.

Moreover, consumers' willingness to buy from local and national producers is another primary outcome of the COVID-19 outbreak that is likely to favor the appearance of a consumer that is "increasingly aware of the impacts of their lifestyle on both the planet and the society" [94]. It also confirms Accenture's results that discovered that $61 \%$ of consumers "are making more environmentally friendly, sustainable or ethical purchases" [97]. Even more than that, the same report shows that out of that $61 \%$ of consumers, a share of $89 \%$ is likely to continue post-crisis with these sustainable changes [97]. The respondents' interest in buying local, together with their increased interest in fresh products, shows another window of opportunity: understanding the global supply chain's fragility (based on their own experience during the COVID-19 outbreak), respondents turned to local products. They stuck with them also when restrictions were not so strict on the national level. Such a trend is likely to stick around given that it has become a lifestyle habit that is enforced with every day that the consumer spends under exceptional, rocky circumstances.

All in all, these research results show how significant changes were a part of people's every aspect of life, starting from their view on the level of certainty they experience in their professional life and with their financial situation, towards understating their perceptions and their consumption choices. Based on the fact that most May results were consistent with the December results, these changes seem to stay here. At the same time, we cannot ignore the fact that there were a few changes between May and December that might already be signaling that the window of opportunity is closing on the long-lasting consumer behavior changes.

\section{Conclusions}

All in all, the present research results confirm once again that crisis moments are also opportunities for embracing changes. Consumers' perceptions, estimations, and evaluations on their financial status and their consumption habits confirm other results that argue that economic uncertainty and job insecurities caused by COVID-19 will determine consumers' reassessment of their values, together with embracing new consumption habits [96]. Therefore, as this paper's central argument shows, crisis moments like the one generated by the COVID-19 outbreak seem to be compelling windows of opportunity in developing new behaviors in what and how people consume different products. More 
specifically, times of uncertainty are the perfect catalyst that causes a re-evaluation of consumption values, behaviors, perceptions, and, ultimately, actions.

Nonetheless, the research limitations are not to be ignored, together with the possibility of getting a better (or even a different understanding) should these limitations be overcome. Among these limitations, we can include the exclusive focus on the Romanian consumer, the principle of sample building (as a longitudinal study would have been more fitted for comparisons across different periods), and the possible distortions that may arise in evaluating perceptions, as opposed to real-life actions. Future research directions may bring a new understanding of this subject by expanding the research population and including other country typologies for increased relevance. Further, developing longitudinal studies might be the key to evaluating how behaviors are changing in where they are headed when we refer to consumption, especially sustainable consumption.

Author Contributions: Conceptualization, A.O., M.-F.P., S.-C.C., F.B., M.S.F. and C.-C.R.-A.; methodology, A.O., M.-F.P. and F.B.; formal analysis, A.O.; data curation, A.O.; writing-original draft, A.O., M.-F.P. and C.-C.R.-A.; writing-review and editing, A.O., M.-F.P. and F.B.; supervision, S.-C.C. and C.-C.R.-A.; funding acquisition, S.-C.C. and M.S.F.; project administration, A.O., M.-F.P. and C.-C.R.-A. All authors have read and agreed to the published version of the manuscript.

Funding: The article was funded by project CNFIS-FDI-2019-0210 entitled "Increasing the institutional capacity to support ESA's excellence research by creating an advanced research pole connected to the priority research directions within the European Union (ASE PLUS)".

Institutional Review Board Statement: Ethical review and approval were waived for this study, due to the research design that ensured $100 \%$ the respondents' anonymity, since no name, e-mail address or any other personal data were collected. The data gathering was conducted by the iSense Solutions research company, on a contract base.

Informed Consent Statement: The collection of information through the questionnaire was done anonymously, without requiring respondents to specify personal information.

Data Availability Statement: The data presented in this study are available on request from the corresponding author. The data are not publicly available due to privacy.

Conflicts of Interest: The authors declare no conflict of interest.

\section{References}

1. Solomon, M.R. Consumer Behavior: Buying, Having, and Being; Pearson Education, Limited: London, UK, 2019; ISBN 978-1-292-31810-3.

2. Wherry, D.F.F.; Woodward, D.I. The Oxford Handbook of Consumption; Oxford University Press: New York, NY, USA, 2019; ISBN 978-0-19-069561-3.

3. Gora, A.A.; Ștefan, S.C.; Popa, S.C.; Albu, C.F. Students' Perspective on Quality Assurance in Higher Education in the Context of Sustainability: A PLS-SEM Approach. Sustainability 2019, 11, 4793. [CrossRef]

4. Arnould, E.J.; Thompson, C.J. Consumer Culture Theory; SAGE: Newcastle upon Tyne, UK, 2018; ISBN 978-1-5264-5211-5.

5. Cross, S.N.N.; Ruvalcaba, C.; Venkatesh, A.; Belk, R.W. Consumer Culture Theory; Emerald Group Publishing: Bingley, UK, 2018; ISBN 978-1-78754-504-5.

6. Schouten, J.; Martin, D.; Belk, R.W. Consumer Culture Theory; Emerald Group Publishing: Bingley, UK, 2014; ISBN 978-1-78441-157-2.

7. Cardigo, C.; Rita, P. Fostering Sustainable Consumption Practices Through Consumer Empowerment. ACR Eur. Adv. 2011, 9 , 502-503.

8. Dolan, P. The Sustainability of "Sustainable Consumption". J. Macromark. 2002, 22, 170-181. [CrossRef]

9. Schwartz, A. 5 Lessons from the Companies Making Sustainability More Profitable Than Ever. Available online: https:// www.fastcompany.com/1681339/5-lessons-from-the-companies-making-sustainability-more-profitable-than-ever (accessed on 1 April 2021).

10. Caradonna, J.L. (Ed.) Routledge Handbook of the History of Sustainability; Routledge, Taylor \& Francis Group: London, UK; New York, NY, USA, 2018; ISBN 978-1-138-68579-6.

11. Caradonna, J.L. Sustainability: A History; Oxford University Press: Oxford, UK; New York, NY, USA, 2014.

12. McKibben, B. Opinion I Buzzless Buzzword. The New York Times, 10 April 1996.

13. Rodriguez, R.S.; Ürge-Vorsatz, D.; Barau, A.S. Sustainable Development Goals and Climate Change Adaptation in Cities. Nat. Clim. Chang. 2018, 8, 181-183. [CrossRef]

14. Sachs, J. Common Wealth: Economics for a Crowded Planet; Penguin: New York, NY, USA, 2008.

15. Sachs, J. The End of Poverty: Economic Possibilities for Our Time; Penguin: New York, NY, USA, 2006. 
16. Gupta, K.; Singh, N. Consumption Behaviour and Social Responsibility: A Consumer Research Approach; Springer Nature: Basingstoke, UK, 2020; ISBN 981153005X.

17. Malyan, R.S.; Duhan, P. Green Consumerism: Perspectives, Sustainability, and Behavior; CRC Press: Boca Raton, FL, USA, 2018; ISBN 1-351-13803-0.

18. Herrick, C. Governing Health and Consumption: Sensible Citizens, Behaviour and the City; Policy Press: Bristol, UK, 2011; ISBN 1-84742-639-5.

19. Schiffman, L.G.; Wisenblit, J.; Kumar, S.R. Consumer Behavior; Pearson Education India: Delhi, India, 2019; ISBN 978-93-5394-380-6.

20. Slater, D. The Moral Seriousness of Consumption. J. Consum. Cult. 2010, 10, 283.

21. Sassatelli, R. Consumer Culture: History, Theory and Politics; SAGE: London, UK, 2007; ISBN 978-1-4462-2499-1.

22. Figueroa-García, E.C.; García-Machado, J.J.; Perez-Bustamante Yabar, D.C. Modeling the Social Factors That Determine Sustainable Consumption Behavior in the Community of Madrid. Sustainability 2018, 10, 2811. [CrossRef]

23. Zrałek, J. Sustainable Consumption in a Trap: Attitude-Behavior Gap and Its Rationalization. Ann. Univ. Mariae Curie-Skłodowska Sect. H Oeconomia 2017, 51, 281-289. [CrossRef]

24. Pagiaslis, A.; Krontalis, A.K. Green Consumption Behavior Antecedents: Environmental Concern, Knowledge, and Beliefs. Psychol. Mark. 2014, 31, 335-348. [CrossRef]

25. Junaedi, S. The Role of Income Level in Green Consumer Behavior: Multigroup Structural Equation Model Analysis. In Proceedings of the International Conference on Business and Management, Phuket, Thailand, 6-7 September 2012; pp. 6-7.

26. Constantinescu, M. Romanian Consumer's Perception on Quality of Life-Sport Relationship. Manag. Mark. 2012, 7, 731-748.

27. Kiraci, H.; Kayabasi, A. Real and Spurious Sustainable Consumption Behavior in Turkey: A Field Research. Innov. Mark. 2010, 6, 43-47.

28. Booi-Chen, T.A.N.; Teck-Chai, L.A.U. Examining Sustainable Consumption Patterns of Young Consumers: Is There a Cause for Concern? J. Int. Soc. Res. 2009, 2, 465-472.

29. Friedl, B.; Pack, A. Sustainable Food Consumption: Trends and Opportunities. 2008. Available online: https://www.researchgate. net/profile/Ines-Omann/publication/238730287_SUFOTROP_Sustainable_Food_Consumption_Trends_and_Opportunities / links /02e7e533b23678e057000000/SUFOTROP-Sustainable-Food-Consumption-Trends-and-Opportunities.pdf (accessed on 31 March 2021).

30. Corral-Verdugo, V.; Fraijo-Sing, B.; Pinheiro, J.Q. Sustainable Behavior and Time Perspective: Present, Past, and Future Orientations and Their Relationship with Water Conservation Behavior. Interam. J. Psychol. 2006, 40, 139-147.

31. Haron, S.A.; Paim, L.; Yahaya, N. Towards Sustainable Consumption: An Examination of Environmental Knowledge among Malaysians. Int. J. Consum. Stud. 2005, 29, 426-436. [CrossRef]

32. do Amaral Junior, A.; De Almeida, L.; Vieira, L.K. Sustainable Consumption: The Right to a Healthy Environment; Springer Nature: Basingstoke, UK, 2019.

33. Reisch, L.A.; Thøgersen, J. Research on sustainable consumption: Introduction and overview. In Handbook of Research on Sustainable Consumption; Edward Elgar Publishing: Cheltenham, UK, 2015.

34. United Nations. Rio Declaration on Environment and Development. In Proceedings of the United Nations Conference on Environment and Development, Rio de Janeiro, Brazil, 3-14 June 1992.

35. Department of Economic and Social Affairs. United Nations Guidelines for Consumer Protection; United Nations: New York, NY, USA, 2003.

36. United Nations. Transforming Our World: The 2030 Agenda for Sustainable Development; United Nations: New York, NY, USA, 2015.

37. Lindstrom, M. Buyology: Warum Wir Kaufen, Was Wir Kaufen; Campus Verlag: Frankfurt, Germany, 2009.

38. First Person: COVID-19 Is Not a Silver Lining for the Climate, Says UN Environment Chief. Available online: https://news.un. org/en/story/2020/04/1061082 (accessed on 31 March 2021).

39. COVID-19 and the Nature Trade-off Paradigm. Available online: http://www.unep.org/news-and-stories/story/covid-19-andnature-trade-paradigm (accessed on 31 March 2021).

40. Parsons, E.; Maclaran, P. Contemporary Issues in Marketing and Consumer Behaviour; Routledge: London, UK, 2009; ISBN 1-136-44155-7.

41. Ritzer, G.; Goodman, D.; Wiedenhoft, W. Theories of consumption. In Handbook of Social Theory; Sage: London, UK, 2001.

42. Miller, D.; Jackson, P.; Rowlands, M.; Thrift, N.; Holbrook, B. Shopping, Place, and Identity; Psychology Press: Hove, UK, 1998.

43. Slater, D. Consumer Culture and Modernity; Polity Press: Cambridge, UK, 1997.

44. Singh, P.R. Consumer Culture and Postmodernism. Postmod. Open 2011, 2, 55-88. [CrossRef]

45. Featherstone, M. Consumer Culture and Postmodernism; Sage: London, UK, 2007.

46. McCracken, G.D. Culture and Consumption II: Markets, Meaning, and Brand Management; Indiana University Press: Bloomington, IN, USA, 2005; Volume 2.

47. Boden, S.; Williams, S.J. Consumption and Emotion: The Romantic Ethic Revisited. Sociology 2002, 36, 493-512. [CrossRef]

48. Featherstone, M. Perspectives on Consumer Culture. Sociology 1990, 24, 5-22. [CrossRef]

49. McCracken, G.D. Culture and Consumption: New Approaches to the Symbolic Character of Consumer Goods and Activities; Indiana University Press: Bloomington, IN, USA, 1990; Volume 1.

50. McCracken, G. Culture and Consumption: A Theoretical Account of the Structure and Movement of the Cultural Meaning of Consumer Goods. J. Consum. Res. 1986, 13, 71-84. [CrossRef] 
51. Campbell, C. The Romantic Ethic and the Spirit of Modern Consumerism; Springer: Oxford, UK, 1987.

52. Deutsch, T. Building a Housewife's Paradise: Gender, Politics, and American Grocery Stores in the Twentieth Century; University of North Carolina Press: Chapel Hill, NC, USA, 2010; ISBN 978-0-8078-3327-8.

53. Shah, D.V.; McLeod, D.M.; Friedland, L.; Nelson, M.R. The Politics of Consumption/the Consumption of Politics; Sage Publications: Los Angeles, CA, USA, 2007.

54. McGovern, C. Sold American: Consumption and Citizenship, 1890-1945; University of North Carolina Press: Chapel Hill, NC, USA, 2006; ISBN 978-0-8078-3033-8.

55. Cohen, L. A Consumers' Republic: The Politics of Mass Consumption in Postwar America. J. Consum. Res. 2004, 31, 236-239. [CrossRef]

56. Ritzer, G. A Consumers' Republic: The Politics of Mass Consumption in Postwar America; JSTOR: New York, NY, USA, 2004.

57. Kroen, S. A Political History of the Consumer. Hist. J. 2004, 47, 709-736. [CrossRef]

58. Cross, G. An All-Consuming Century: Why Commercialism Won in Modern America; Columbia University Press: New York, NY, USA, 2000; ISBN 978-0-231-50253-5.

59. Glickman, L.B. A Living Wage: American Workers and the Making of Consumer Society; Cornell University Press: Ithaca, NY, USA, 1999; ISBN 978-0-8014-8614-2.

60. Voss, K.; Voss, P. of S.K. The Making of American Exceptionalism: The Knights of Labor and Class Formation in the Nineteenth Century; Cornell University Press: Ithaca, NY, USA, 1993; ISBN 978-0-8014-2882-1.

61. Ekström, K.M.; Brembeck, H. Elusive Consumption; Routledge: Oxon, UK, 2020; ISBN 978-1-00-018282-8.

62. Hyman, L.; Tohill, J. Shopping for Change: Consumer Activism and the Possibilities of Purchasing Power; Cornell University Press: Ithaca, NY, USA, 2017; ISBN 978-1-5017-1263-0.

63. Hilton, M. Prosperity for All: Consumer Activism in an Era of Globalization; Cornell University Press: Ithaca, NY, USA, 2011; ISBN 978-0-8014-6163-7.

64. Glickman, L.B. Buying Power: A History of Consumer Activism in America; University of Chicago Press: Chicago, IL, USA, 2009; ISBN 978-0-226-29866-5.

65. Breen, T.H. The Marketplace of Revolution: How Consumer Politics Shaped American Independence; Oxford University Press: Oxford, UK, 2005; ISBN 978-0-19-518131-9.

66. Ehrlich, P.; Ehrlich, A. The Population Explosion; Simon \& Schuster: New York, NY, USA, 1990.

67. Ehrlich, P. The Population Bomb; Sierra Club/Ballantine Books: New York, NY, USA, 1968.

68. Myers, N.; Kent, J. New Consumers: The Influence of Affluence on the Environment. Proc. Natl. Acad. Sci. USA 2003, 100, 4963-4968. [CrossRef]

69. Voicu-Dorobantu, R. European Regions and Entrepreneurial Ecosystems in the Context of the New Sustainable Development Goals. J. East. Eur. Res. Bus. Econ. 2016, 2016, 1-16. [CrossRef]

70. Onete, B.; Constantinescu, M.; Filip, A. Main Issues Regarding the Relationship between Cognitive Maps and Internet Consumer Behavior-A Knowledge Based Approach. Amfiteatru Econ. J. 2007, 9, 115-120.

71. Murphy, W.W. Consumer Culture and Society; SAGE Publications: Los Angeles, CA, USA, 2016; ISBN 978-1-4833-5814-7.

72. Programme, U.N.D. Human Development Report 1998; Oxford University Press: Oxford, UK, 1998; ISBN 978-0-19-512459-0.

73. Galbraith, J.K. The Affluent Society; Houghton Mifflin Harcourt: Boston, MA, USA, 1998.

74. Baudrillard, J. The Consumer Society: Myths and Structures; SAGE: Newcastle upon Tyne, UK, 2016; ISBN 978-1-4739-9454-6.

75. Stephens, D.L. Essentials of Consumer Behavior; Taylor \& Francis: Abingdon, UK, 2016; ISBN 1-317-64885-4.

76. Ling, P.; D'Alessandro, S.; Winzar, H. Consumer Behaviour in Action; Oxford University Press: Victoria, Hong Kong, 2015.

77. Schiffman, L.G.; Kanuk, L.; Hansen, H. Consumer Behaviour-A European Outlook; Pearson Education: London, UK, 2013; ISBN 978-0-273-72425-4.

78. Foxall, G.R. Consumer Behaviour: A Practical Guide; Routledge: New York, NY, USA, 2014.

79. Graves, P. Consumerology: The Truth about Consumers and the Psychology of Shopping; Hachette UK: London, UK, 2013; ISBN 978-1-85788-923-9.

80. Mothersbaugh, D.L.; Hawkins, D.I.; Kleiser, S.B. Consumer Behavior: Building Marketing Strategy; McGraw-Hill Education: New York, NY, USA, 2019; ISBN 978-1-260-10004-4.

81. Smith, A. Consumer Behaviour and Analytics: Data Driven Decision Making; Routledge: Oxford, UK; New York, NY, USA, 2019.

82. Noel, H. Basics Marketing 01: Consumer Behaviour; Bloomsbury Publishing: London, UK, 2017; ISBN 978-1-350-03466-2.

83. Baudrillard, J. The System of Objects; Verso: London, UK, 2005; ISBN 978-1-84467-053-6.

84. Baudrillard, J. The System of Objects. Art Mon. 1988, 115, 5.

85. Zaccaï, E. Sustainable Consumption, Ecology and Fair Trade; Routledge: Oxon, UK, 2007.

86. Kotler, P.; Kartajaya, H.; Setiawan, I. Marketing 4.0: Moving from Traditional to Digital; John Wiley \& Sons: Manhattan, NY, USA, 2016; ISBN 978-1-119-34114-7.

87. Kotler, P.; Kartajaya, H.; Setiawan, I. Marketing 5.0: Technology for Humanity; John Wiley \& Sons: Manhattan, NY, USA, 2021; ISBN 1-119-66854-9.

88. Kopka, U.; Little, E.; Moulton, J.; Schmutzler, R.; Simon, P. What Got Us Here Won't Get Us There: A New Model for the Consumer Goods Industry; McKinsey: New York, NY, USA, 2020. 
89. Radulescu, C.V.; Ladaru, G.-R.; Burlacu, S.; Constantin, F.; Ioanăș, C.; Petre, I.L. Impact of the COVID-19 Pandemic on the Romanian Labor Market. Sustainability 2021, 13, 271. [CrossRef]

90. United Nations Environment Programme Food Waste Index Report 2021; United Nations Environment Programme: Nairobi, Kenya, 2021.

91. Ferguson, B.; Thompson, C. Why Buy Local? J. Appl. Philos. 2021, 38, 104-120. [CrossRef]

92. Vermeir, I.; Weijters, B.; De Houwer, J.; Geuens, M.; Slabbinck, H.; Spruyt, A.; Van Kerckhove, A.; Van Lippevelde, W.; De Steur, H.; Verbeke, W. Environmentally Sustainable Food Consumption: A Review and Research Agenda From a Goal-Directed Perspective. Front. Psychol. 2020, 11, 1603. [CrossRef]

93. Solomon, M.R.; Bamossy, G.; Askegaard, S.; Hogg, M.K. Consumer Behaviour: A European Perspective; Pearson: Edinburgh Gate, UK, 2016; ISBN 978-1-292-11672-3.

94. Euromonitor. From Sustainability to Purpose: New Values Driving Purpose-Led Innovation; Euromonitor International: London, UK, 2020.

95. Druică, E.; Musso, F.; Ianole-Călin, R. Optimism Bias during the Covid-19 Pandemic: Empirical Evidence from Romania and Italy. Games 2020, 11, 39. [CrossRef]

96. Euromonitor. Emerging Markets' Middle Class Consumers in the Coronavirus Era; Euromonitor International: London, UK, 2020.

97. Accenture COVID-19: Retail Consumer Habits Shift Long-Term I Accenture. Available online: https://www.accenture.com/usen/insights/retail/coronavirus-consumer-habits (accessed on 1 April 2021). 